\title{
Identifikasi Spasial Serangan Parasit Cacing pada Ternak Sapi di Kalimantan Tengah
}

\author{
(Spatial Identification of Worm Parasite Attack on Beef Cattle in Central \\ Kalimantan)
}

\author{
Bhermana A, Haryanto B, Adrial, Munier FF \\ Balai Pengkajian Teknologi Pertanian Kalimantan Tengah \\ Jl. G Obos Km. 5, Palangka Raya, Kalimantan Tengah \\ andybhermana@yahoo.com; bangharyanto84@gmail.com
}

\begin{abstract}
In Central Kalimantan, the health of cattle can be affected by environmental biophysic factor and its impacts include low productivity and the decrease of cattle population. Environmental factor has closely related to both feed availability and existence of parasite presence on beef cattle. The objectives of this study was to develop both data dan information related to location of parasitic attack whether it has been existed or happened at present. The application of geographic information system (GIS) was used in order to include spatial aspect as the object of spatial analysis. The result of spatial identification then provide geographical information that can be used as basic consideration to identify areas that have the potency of parasitic attack so that prevention and control intervention can be performed and also as recommendation for planning of beef cattle development in Central Kalimantan. The results showed that parasitic attack dominated by Fasciola $s p$ was mainly found at wetland typology. The development of beef cattle can then be recommended and allocated to uplands. The geographical pattern of this dryland typology represent spatial unity, located in Kotawaringin Barat, Seruyan, Kotawaringin Timur, Katingan and Pulang Pisau regency. While for wetlands, the development of beef cattle can still be continued with additional introduction of livestock technology innovation for specific location in which including health of cattle beef and environmental biophysic management.
\end{abstract}

Key Words: Identification, Spatial, Parasite, Beef Cattle, Central Kalimantan

\begin{abstract}
ABSTRAK
Salah satu faktor kendala yang mengakibatkan rendahnya produktivitas yang sejalan dengan penurunan jumlah populasi ternak di Kalimantan Tengah antara lain adalah faktor biofisik lingkungan yang berdampak pada produktivitas yang rendah dan menurunnya populasi. Faktor lingkungan sangat berpengaruh selain terhadap ketersediaan pakan juga sangat berhubungan erat dengan keberadaan parasit pada ternak sapi. Tujuan dari penelitian ini adalah untuk menyusun data dan informasi lokasi keberadaan di mana serangan parasit ini pernah muncul atau sedang terjadi. Aplikasi sistem informasi geografis (GIS) digunakan untuk menambahkan dimensi ruang (spatial) yang menghasilkan objek untuk keperluan analisis spasial. Hasil identifikasi spasial menyajikan informasi geografis yang dapat dijadikan sebagai dasar pertimbangan dalam upaya untuk mengetahui kawasan yang berpotensi terjadinya serangan parasit sehingga penanggulangan serta intervensi pengendalian dapat dilakukan, juga sebagai rekomendasi untuk perencanaan pengembangan ternak sapi di Kalimantan Tengah. Hasil penelitian menunjukkan bahwa serangan parasit yang didominasi oleh jenis Fasciola sp. secara umum banyak terdapat pada tipologi lahan basah. Dengan demikian pengembangan usaha ternak sapi dapat diarahkan pada tipologi lahan kering yang secara geografis memiliki pola spasial berbentuk suatu kesatuan hamparan terdapat pada kabupaten Kotawaringin Barat, Seruyan, Kotawaringin Timur, Katingan dan Pulang Pisau. Sedangkan pada lahan-lahan basah usaha ternak tetap dapat dikembangkan namun dengan mengintroduksikan teknologi inovasi spesifik lokasi yang di dalamnya sudah mencakup manajemen kesehatan ternak dan biofisik lingkungannya.
\end{abstract}

Kata Kunci: Identifikasi, Spasial, Parasit, Sapi Potong, Kalimantan Tengah 


\section{PENDAHULUAN}

Kalimantan Tengah dengan luas wilayah mencapai 15 juta ha mempunyai potensi besar untuk pengembangan sapi potong karena didukung oleh ketersediaan potensi lahan dan sumber daya lokal yang melimpah, namun hingga saat ini jumlah populasi sapi potong di Kalimantan Tengah hanya menempati urutan ke 29 dari 33 Provinsi di Indonesia dengan kontribusi populasi terhadap populasi sapi potong nasional sebesar $0,41 \%$ dan produksi daging sebesar $0,81 \%$. Jika dilihat dari data perkembangan populasi dalam 5 tahun terakhir juga terlihat bahwa pertumbuhan sapi potong di Kalimantan Tengah tahun 2010-2014 mengalami pertumbuhan negatif $(-19,87 \%)$ dengan rata-rata penurunan populasi sekitar $-3,1 \%$ per tahun. Hingga tahun 2015 jumlah populasi ternak sapi di seluruh wilayah Kalimantan Tengah adalah 68.531 ekor (BPS Kalimantan Tengah 2016). Penurunan populasi ini umumnya terjadi di beberapa sentra keberadaan populasi sapi potong seperti di Kabupaten Pulang Pisau, Kapuas, Kotawaringin Barat dan Kotawaringin Timur.

Salah satu faktor kendala yang dihadapi dalam usaha ternak sapi di Kalimantan Tengah yang mengakibatkan rendahnya produktivitas yang sejalan dengan penurunan jumlah populasi ternak antara lain adalah faktor biofisik lingkungan. Faktor lingkungan sangat berpengaruh terhadap ketersediaan pakan juga berhubungan erat dengan serangan parasit pada ternak sapi. Kekurangan gizi dalam pakan dan disertai adanya penyakit parasit terutama cacingan sebagai akibat pola pemeliharaan yang belum menerapkan teknologi budidaya ternak yang sesuai diduga menjadi faktor penghambat tidak optimalnya usaha ternak sapi di Kalimantan Tengah (Adrial et al. 2016). Lebih lanjut faktor lingkungan memiliki hubungan erat dengan sistem pemeliharaan ternak, khususnya pada sistem pemeliharaan ekstensif (digembalakan) dan semi-ekstensif dimana usaha ternak dilakukan dengan cara memelihara ternak di lingkungan tempat tinggal dan tidak dikandangkan. Kondisi inilah yang menjadikan faktor lingkungan berpengaruh langsung terhadap perkembangan ternak. Selain faktor ketersediaan nutrisi baik secara kualitas maupun kuantitas, kondisi biofisik lingkungan pada sistem pemeliharaan ekstensif dan semiekstensif juga berpengaruh terhadap potensi munculnya berbagai serangan parasit pada pemeliharaan ternak sapi. Kotoran ternak yang dihasilkan dan terpapar pada lingkungan sekitar penggembalaan menciptakan habitat bagi munculnya parasit dan penyakit (Suhardono et al. 1999).

Salah satu serangan parasit yang banyak dijumpai di wilayah Kalimantan Tengah adalah fasciolosis. Serangan cacing (helmintiasis) dapat menyebabkan kondisi kronis yang menahun, kekurangan darah dan gizi, pertumbuhan menjadi lambat serta menimbulkan peradangan hati dan empedu pada ternak. Infeksi ringan yang berkepanjangan juga mengakibatkan ternak tidak dapat gemuk, kondisi tubuh melemah, nafsu makan menurun, pembengkakan di bawah rahang, perut busung dan dapat menyebabkan kematian (Martindah et al. 2005).

Upaya untuk mencegah terjadinya penyakit ini diperlukan data dan informasi lokasi keberadaan di mana gejala serangan parasit ini pernah muncul atau sedang terjadi. Berdasarkan informasi ini diharapkan pencegahan dan penanganan serta intervensi pengendalian dapat dilakukan dalam rangka mendukung peningkatan dan optimalisasi produktivitas pada usaha ternak sapi di Kalimantan Tengah. Penyusunan data dan informasi dilakukan berdasarkan hasil analisis spasial sebagai upaya untuk melengkapi aspek spasial sehingga dapat membantu dalam analisis dan evaluasi informasi keberadaan penyakit ternak secara geografis wilayah meliputi pola sebaran spasial dan visual trend yang terjadi di lapangan (Coleman \& Galbraith 2000). Aplikasi sistem informasi geografis (geographic information system/GIS) digunakan dalam penelitian ini untuk menyusun format data spasial dan tabular yang terintegrasi (Richard et al. 2005; Bhermana et al. 2002). 
Tujuan dari penelitian ini adalah untuk menyusun data dan informasi pola sebaran kejadian penyakit dan parasit pada usaha ternak sapi potong pada sistem pemeliharaan ekstensif dan semi-ekstensif. Hasil dari pewilayahan ini dapat dimanfaatkan dalam penyusunan perencanaan kawasan pengembangan usaha ternak sapi dan rekomendasi penanggulangan serangan parasit berdasarkan prioritas kewilayahan sebagai upaya untuk meningkatkan populasi dan produktivitas di Kalimantan Tengah.

\section{MATERI DAN METODE}

Kegiatan penelitian dilaksanakan pada tahun 2016 pada beberapa wilayah administrasi kabupaten di Kalimantan Tengah melalui survei lapangan (field survey) untuk mengidentifikasi lokasi-lokasi keberadaan kejadian. Pengumpulan data sekunder dilakukan sebelumnya untuk menentukan lokasi survei dengan pendekatan purposive sampling. Sedangkan data primer yang dikumpulkan meliputi data lokasi dan posisi geografis keberadaan kejadian serangan parasit dan jenis penyakit atau parasit pada usaha ternak sapi.

Aplikasi GIS digunakan pada penelitian ini dengan menggunakan perangkat Global Positioning System (GPS) untuk pengumpulan data spasial di lapangan sedangkan untuk pengolahan dan analisis data spasial menggunakan perangkat lunak (software) Arc-View 3.2 (USAID 2002; Laurini \& Thompson 1992). Pada proses pemetaan (mapping process) digunakan teknik analisis buffer dan tumpang tepat (overlay technique). Analisis buffer digunakan untuk mengidentifikasi daerah cakupan (range) di sekitar fitur geografis berupa data atribut titik (point) hasil rekaman GPS. Sedangkan teknik overlay digunakan untuk menyajikan data hasil integrasi gabungan beberapa peta data sumberdaya lahan dan iklim untuk penentuan pewilayahan terhadap fitur geografis hasil dari survei lapangan dan rekaman GPS. Secara umum alur pelaksanaan kegiatan penelitian disajikan pada Gambar 1 .

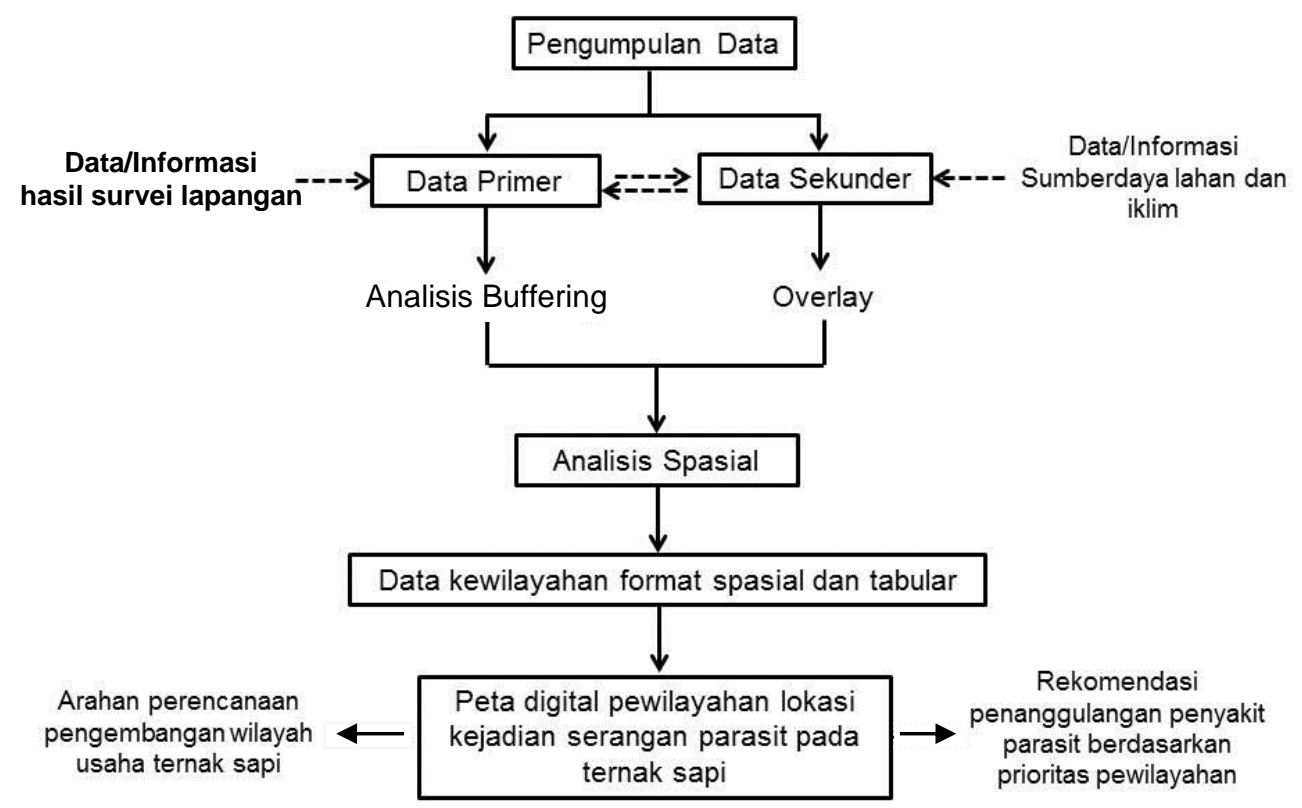

Gambar 1. Alur pelaksanaan penelitian 


\section{HASIL DAN PEMBAHASAN}

\section{Kondisi umum biofisik lingkungan wilayah Kalimantan Tengah dan hubungannya dengan serangan parasit pada usaha ternak sapi}

Secara geografis, wilayah Kalimantan Tengah terletak pada garis khatulistiwa (equator) tepatnya di bagian bawah (Selatan) pada posisi koordinat antara $110^{\circ} 42^{\prime} 48^{\prime \prime}$ -

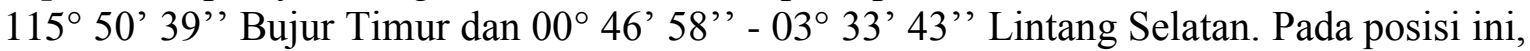
wilayah Kalimantan Tengah mendapat penyinaran matahari yang cukup sepanjang tahun dengan rata-rata suhu minimum $22,6^{\circ} \mathrm{C}$ dan suhu maksimum $32,08^{\circ} \mathrm{C}$. Perbedaan suhu antar lokasi relatif kecil dan hanya dibedakan oleh perbedaan altitude. Suhu relatif pada siang hari berkisar antara $26-30^{\circ} \mathrm{C}$ sedangkan pada malam hari $15-26^{\circ} \mathrm{C}$ dengan kelembaban 82,09-87,85\% (Badan Pusat Statistik Kalimantan Tengah 2016).

Hasil pantauan terakhir BMKG (2017) intensitas hujan bulanan di wilayah Kalimantan Tengah berkisar antara 191-318 mm/bulan. Hasil rekapitulasi data curah hujan 10 tahun terakhir hingga tahun 2012 berdasarkan data stasiun-stasiun iklim Kota Palangkaraya, Pangkalan Bun, Sampit, Muara Teweh dan Buntok, curah hujan tahunan wilayah ini berkisar antara $2.297 \mathrm{~mm}$ hingga $3.812 \mathrm{~mm}$ (BMKG 2012). Periode bulan basah berturut-turut berkisar antara 10-12 bulan sedangkan bulan kering antara 0-2 bulan. Tingginya curah hujan disebabkan pengaruh suhu yang mengakibatkan tingginya intensitas penguapan sehingga menimbulkan kondisi udara yang jenuh air dan awan aktif yang berpotensi hujan.

Berdasarkan klasifikasi iklim Schimdt-Ferquson, wilayah Kalimantan Tengah termasuk ke dalam tipe hujan A dengan kriteria biofisik kawasan sangat basah dengan vegetasi hutan hujan tropika. Sedangkan berdasarkan klasifikasi iklim Koppen wilayah ini termasuk ke dalam tipe iklim Afa yang dicirikan dengan beriklim tropis, suhu rata-rata tahunan pada bulan terdingin $>18^{\circ} \mathrm{C}$ dan pada bulan terkering curah hujan masih diatas 60 $\mathrm{mm} /$ bulan. Sedangkan hasil analisis spasial berdasarkan peta zona agroklimat (Oldeman et al. 1980), wilayah Kalimantan Tengah terbagi menjadi 4 (empat) zona utama yaitu zona A, $\mathrm{B} 1, \mathrm{C} 1$, dan C2. Zona A terdapat di bagian utara dengan jumlah bulan basah berturut-turut lebih dari 9 bulan dan bulan kering kurang dari 2 bulan, sedangkan di bagian tengah dan sebagian selatan didominasi oleh zona B1 dengan jumlah bulan basah 7-9 bulan dan bulan kering kurang dari 2 bulan. Zona $\mathrm{C} 1$ dan $\mathrm{C} 2$ hanya meliputi kawasan dengan proporsi yang sedikit di bagian selatan dengan dengan jumlah bulan basah 5-6 bulan dan bulan kering kurang dari 2 bulan sampai 3 bulan.

Wilayah provinsi Kalimantan Tengah secara umum terbagi dalam 2 (dua) tipologi lahan yaitu lahan kering (up land) yang berada di bagian tengah dan paling dominan di sebelah utara berbatasan dengan wilayah Kalimantan Barat dan Kalimantan Timur dan lahan basah (wet land) yang tersebar di bagian selatan. Karakteristik lahan kering di wilayah ini sebagian besar terdiri dari tanah-tanah tua yang sudah banyak mengalami pencucian sehingga memiliki tingkat kesuburan yang rendah diperberat dengan ketiadaan bahan pembaharu seperti abu volkan. Sedangkan pada lahan-lahan basah seperti rawa gambut dan lahan pasang surut, faktor pembatas untuk kesuburan tanah adalah kemasaman tanah yang sangat tinggi (Pusat Penelitian Tanah dan Agroklimat 2000; 1995).

Karakteristik topografi Kalimantan Tengah banyak didominasi oleh wilayah-wilayah yang datar mulai dari bagian selatan mengarah ke tengah dan terus ke bagian barat hingga timur. Pada bagian tengah mulai dijumpai perbukitan dengan variasi kisaran lereng dengan tingkat kecuraman yang meningkat ke arah bagian utara. Pada bagian utara rangkaian pegunungan dengan kelerengan yang curam memanjang dari barat daya ke timur. Titik tertinggi untuk wilayah Kalimantan Tengah berada pada elevasi 2.200 meter di atas 
permukaan laut terdapat di daerah sekitar gunung Bukit Raya, Kabupaten Katingan bagian utara berbatasan dengan provinsi Kalimantan Barat. Data mengenai bentuk wilayah (landform) dan topografi sangat penting dalam analisis potensi wilayah karena berhubungan dengan karakteristik tanah dan sifat-sifat lingkungan biofisik lainnya (Djaenudin et al. 2002). Kelerengan (slope) merupakan bagian penting dari topografi yang dapat dijadikan dasar dalam menentukan tipe pemanfaatan lahan (Altiery 1987). Dalam keterkaitannya dengan usaha ternak, faktor biofisik lingkungan secara dominan berpengaruh terhadap ketersediaan pakan khususnya pada sistem pemeliharaan ekstensif dan semi-ekstensif (Prasetyo \& Basuki 2010). Selain itu dampak lingkungan juga berpengaruh pada kesehatan lingkungan (health environment) yang pada akhirnya berimbas pada kesehatan ternak itu sendiri (Riady 2005).

Berdasarkan data dan informasi biofisik lingkungan sebagaimana telah dijelaskan di atas, maka aspek dominan iklim seperti kelembaban dan suhu serta aspek lahan sebagai media hijauan pakan ternak merupakan hal penting dalam usaha ternak di Kalimantan Tengah. Pada sistem pemeliharaan ekstensif di mana ternak merumput di padang penggembalaan, kondisi ternak sangat rentan terhadap terjadinya infeksi parasit mengingat keberadaan lingkungan yang mendukung berkembangnya induk semang antara seperti keong (Lymnaea) dan lain-lain (Ambarisa et al. 2013; Santoso 2006). Pada lahan-lahan basah yang sebagian besar terdapat di bagian Selatan Kalimantan Tengah, peluang terjadinya infeksi parasit pada sapi sangat tinggi. Hal ini dipengaruhi oleh kondisi lahan yang sebagian besar dalam kondisi jenuh air seperti pada tipologi luapan A dan B sehingga hal ini memberikan kesempatan hewan siput sebagai induk semang (hospes) untuk tumbuh dan berkembang biak dengan baik (Subronto \& Tjahayati 2004). Kondisi iklim yang tergolong dalam kategori lembab merupakan faktor yang juga mendukung fase hidup bebas dari berbagai parasit cacing (Beriajaya \& Stevenson 1986). Lebih lanjut, dilaporkan bahwa ternak dapat juga terinfeksi bila memakan rumput yang sudah tercemar oleh metaserkaria (larva infektif) yang merupakan stadium infektif dari parasit cacing seperti Fasciola sp. (Sadarman et al. 2007).

\section{Distribusi spasial potensi pengembangan usaha ternak sapi di Kalimantan Tengah}

Meskipun pengembangan usaha ternak sapi di Kalimantan Tengah belum menunjukkan gambaran hasil yang optimal namun dengan keberadaan sumberdaya lingkungan seperti luas wilayah dan potensi pengembangan hijauan pakan baik rerumputan maupun leguminosa di padang penggembalaan (pasture) yang dapat dikelola maka peluang usaha ternak sapi memiliki prospek yang cukup baik. Pesatnya perkembangan pembangunan perkebunan melalui ekspansi perkebunan sawit hingga saat ini telah memunculkan konsep pola pengembangan integrasi sapi-sawit yang sudah banyak diadopsi oleh perusahaan besar baik swasta maupun pemerintah.

Berdasarkan data yang dikeluarkan oleh Badan Pusat Statistik Kalimantan Tengah (2016), hampir setiap wilayah administrasi kabupaten terdapat ternak sapi dengan total populasi keseluruhan wilayah Kalimantan hingga tahun 2015 mencapai 68.531 ekor. Data sebaran populasi untuk selanjutnya dapat dikonversi ke dalam format spasial untuk kepentingan analisis dan perencanaan. Informasi spasial berupa peta wilayah penyebaran jumlah populasi disajikan dalam Gambar 2.

Hasil analisis spasial menunjukkan bahwa jumlah populasi ternak sapi di tiap kabupaten dengan angka $<5.000$ ekor masih dominan di Kalimantan Tengah. Hanya terdapat satu kabupaten saja yang memiliki jumlah terbanyak $>10.000$ ekor yaitu Kabupaten Kotawaringin Barat. Sedangkan kisaran populasi 5.000-10.000 ekor hanya terdapat di Kabupaten Pulang Pisau, Katingan, Kotawaringin Timur dan Seruyan. Dengan 
demikian program kebijakan pengembangan usaha ternak sapi dapat diarahkan dan diprioritaskan pada 4 kabupaten tersebut termasuk satu kabupaten yaitu Kotawaringin Barat mengingat pola geografis beberapa kabupaten tersebut merupakan suatu kesatuan hamparan. Dengan didukung adanya pembangunan infrastruktur penunjang seperti transportasi jalan ke lokasi usaha dan sarana pendukung lainnya seperti klinik hewan dan pos inseminasi buatan (IB) termasuk teknologi usaha ternak dan manajemen peternakan, maka kawasan ini sangat berpotensi untuk pengembangan usaha ternak sapi potong di Kalimantan Tengah.

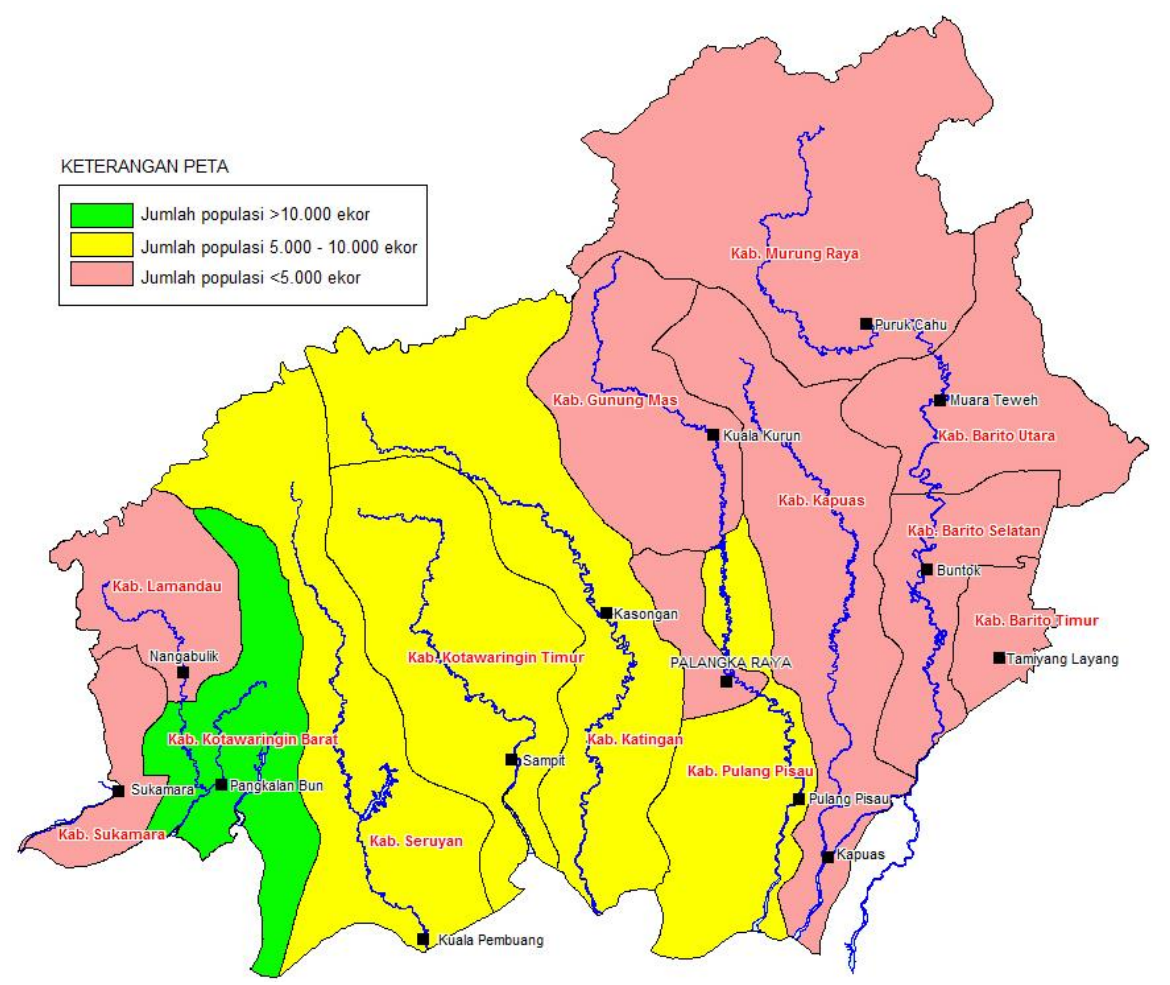

Gambar 2. Distribusi spasial jumlah populasi ternak sapi di Kalimantan Tengah

\section{Identifikasi spasial terhadap serangan parasit cacing pada usaha ternak sapi di Kalimantan Tengah}

Bagian utama dari penelitian ini adalah mengidentifikasi pola sebaran geografis (spasial) keberadaan kejadian adanya serangan parasit pada usaha ternak sapi di Kalimantan Tengah. Aplikasi sistem informasi geografis GIS digunakan untuk membantu dalam pengumpulan data, pengelolaan data dan analisis data spasial untuk kepentingan penyusunan perencanaan wilayah pengembangan dan rekomendasi pewilayahan untuk penetapan intervensi pengelolaan sesuai dengan kondisi lokasi. GIS merupakan suatu sistem informasi yang sangat berguna untuk membantu pengambilan keputusan karena kemampuannya dalam pengelolaan dan menganalisis data parsial dan tekstual. Dengan demikian, informasi yang dihasilkan tidak hanya informasi tekstual atau deskriptif saja tetapi dapat juga diketahui informasi lokasinya (Shereen et al. 2011; Wirosoedarmo et al. 2007; Tomlinson 1968). Aspek-aspek kewilayahan berdasarkan hasil survei identifikasi serangan parasit cacing pada usaha ternak sapi sebagai data input untuk selanjutnya dikelola ke dalam suatu sistem informasi. Teknologi GIS dimanfaatkan untuk mengkonversi dan mentransformasi data ke dalam format sesuai dengan lingkungan GIS untuk keperluan analisis lebih lanjut (Prahasta 2001). 
Beberapa tempat berdasarkan hasil survei lapangan menunjukkan bahwa penyakit parasit cacing pada ternak sapi banyak dijumpai di wilayah Kalimantan Tengah yaitu pada sistem pemeliharaan ekstensif dan semi-ekstensif. Pada sistem pemeliharaan ini, ternak sapi berhubungan langsung dengan lingkungan biofisik setempat karena digembalakan dan tidak dikandangkan. Lokasi-lokasi kejadian dimana terjadi serangan parasit cacing dituangkan ke dalam format spasial yaitu peta digital sebaran lokasi temuan penyakit parasit pada usaha ternak sapi (Gambar 3).

Berdasarkan peta lokasi kejadian serangan parasit (Gambar 3) menunjukkan bahwa jenis parasit yang dijumpai sangat beragam jenisnya seperti Cooperia sp., Paramphistomum sp., Fasciola sp., Trichostrongylus sp. Hasil identifikasi lebih lanjut menunjukkan bahwa terdapat jenis parasit cacing yang hampir selalu dijumpai di setiap lokasi pengamatan yaitu jenis Fasciola sp. dan terdapat di areal penggembalaan yang secara umum terdapat di jalur selatan wilayah Kalimantan Tengah yaitu di Kabupaten Kotawaringin Barat, Kotawaringin Timur dan Pulang Pisau.

Hasil identifikasi secara spasial dengan membandingkan peta lokasi serangan parasit cacing dengan informasi sumberdaya lahan melalui teknik overlay dalam lingkungan GIS, secara spasial lokasi keberadaan parasit cacing pada usaha ternak cenderung lebih banyak terdapat pada tipologi lahan basah (wetlands). Pada kawasan dengan tipologi lahan kering hanya sedikit dijumpai jenis parasit cacing seperti Paramphistomum sp. dan Fasciola sp. Banyaknya kejadian atau keberadaan serangan parasit pada lahan-lahan basah ini dikarenakan pada kawasan ini kondisi biofisik lingkungan yang ada (sumberdaya lahan dan iklim) sangat mendukung perkembangan munculnya habitat induk semang antara parasit cacing yang mengakibatkan kerugian pada usaha ternak secara umum (Ambarisa et al. 2013; Yani \& Purwanto 2006; Suhardono et al. 1999).

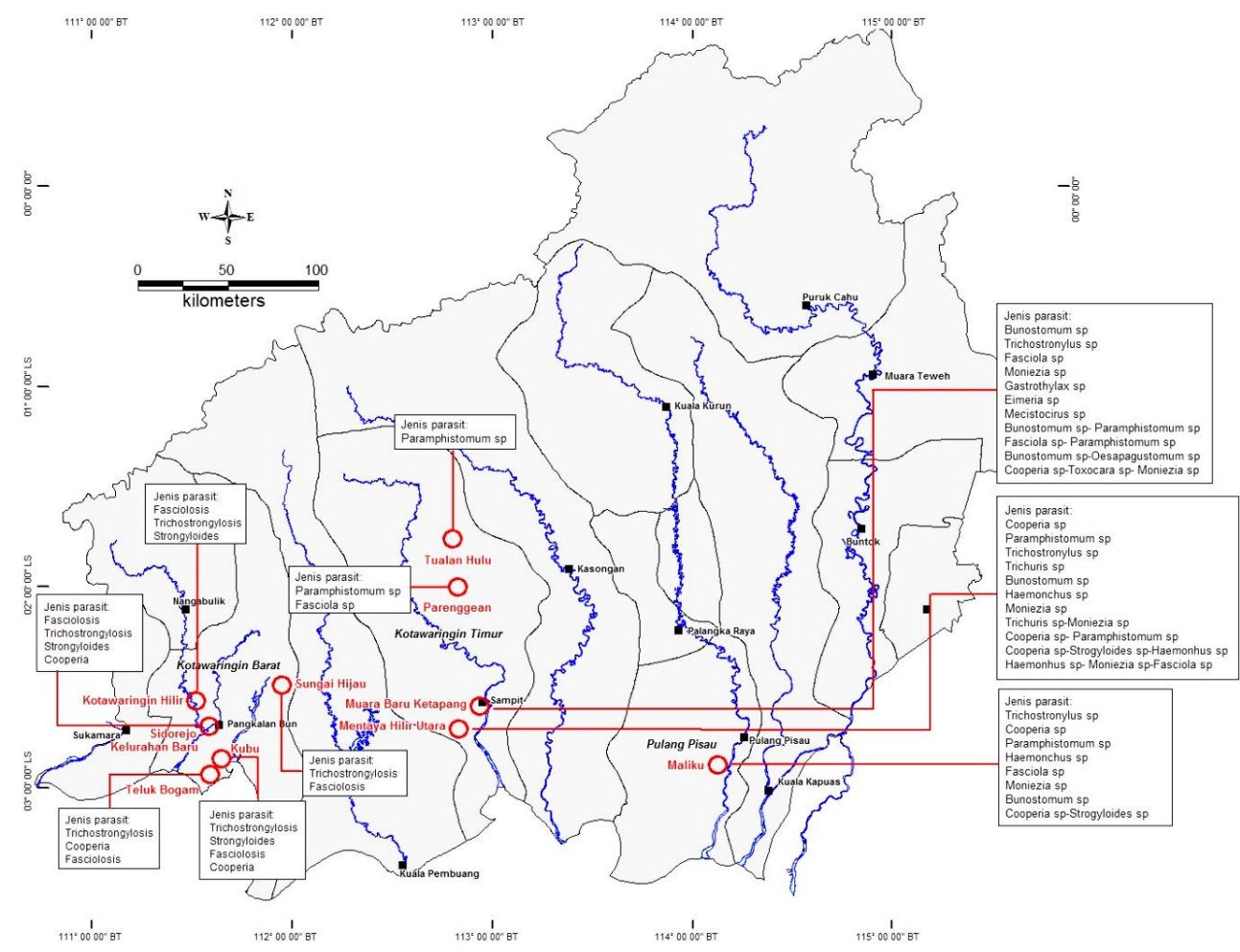

Gambar 3. Lokasi spasial kejadian serangan parasit cacing pada usaha ternak sapi di Kalimantan Tengah

Hasil identifikasi secara spasial lebih lanjut menjelaskan bahwa jenis cacing Fasciola sp. terdapat pada hampir di seluruh lokasi pengamatan selain jenis lainnya. Hal ini 
mengindikasikan bahwa untuk wilayah Kalimantan secara umum masih didominasi oleh serangan fasciolosis. Manajemen ternak terpadu yang menitik beratkan pada pencegahan infeksi parasit cacing yang disertai upaya pengelolaan lingkungan sekitar lahan penggembalaan perlu untuk diformulasi dalam upaya pengembangan usaha ternak di Kalimantan Tengah.

\section{Arahan pewilayahan pengembangan usaha ternak sapi potong berbasis biofisik lingkungan dan potensi serangan parasit cacing}

Aplikasi GIS dalam penelitian ini digunakan mengidentifikasi data vektor berupa titik (point) yang memuat informasi spesifik data kebumian lokasi persekitaran berdasarkan titik lokasi pengamatan (Raju 2004). Pada penelitian ini data vektor diperoleh berdasarkan rekaman GPS hasil survei lapangan pada titik-titik lokasi keberadaan kejadian serangan parasit. Teknik buffering dan overlay selanjutnya digunakan untuk mengidentifikasi area sekitar fitur-fitur geografi dalam zona buffer (Dewi et al. 2005). Informasi sumberdaya lahan dan iklim diintegrasikan dalam lingkungan GIS untuk menghasilkan layer baru dengan informasi baru sebagai objek analisis spasial. Hasil proses buffering dan overlay dihasilkan informasi spasial berupa peta wilayah geografis untuk kawasan yang berpotensi terjadinya serangan parasit cacing pada usaha ternak sapi potong di Kalimantan Tengah (Gambar 4).

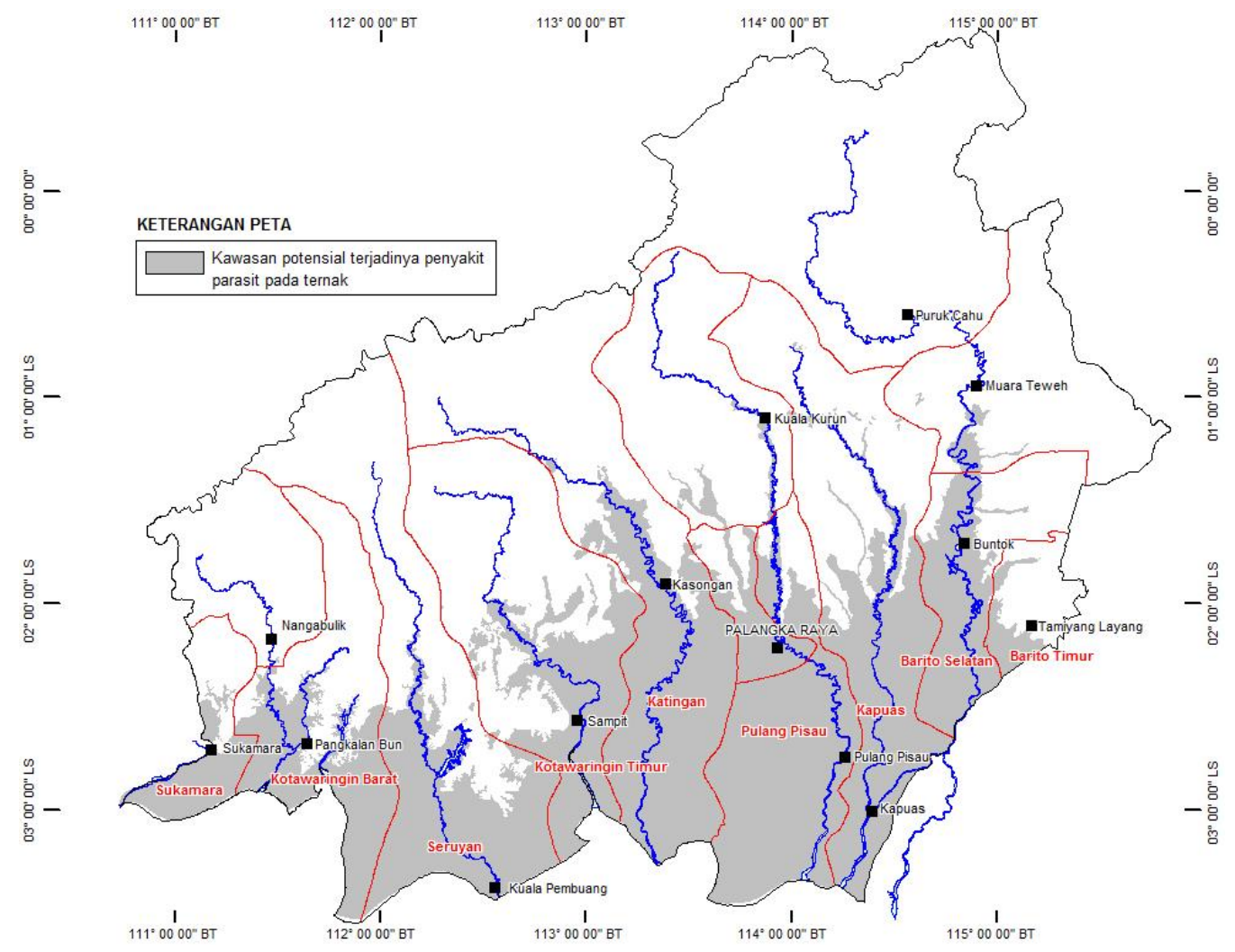

Gambar 4. Pewilayahan kawasan potensial serangan parasit cacing berdasarkan biofisik lingkungan di Kalimantan Tengah

Hasil analisis spasial terhadap lokasi sebaran serangan parasit cacing berdasarkan kondisi biofisik lingkungan menjelaskan bahwa potensi penyakit parasit ternak cenderung terdapat di bagian selatan wilayah Kalimantan yang didominasi oleh lahan basah meliputi lahan pasang surut dan lahan gambut. Kondisi lahan basah dan lembab merupakan media 
yang paling ideal untuk berkembangnya larva parasit cacing (Suhardono et al. 1999; Anggriana 2014). Untuk kepentingan perencanaan wilayah pengembangan, maka pengembangan usaha ternak sapi potong sebaiknya diarahkan pada tipologi lahan kering yaitu di bagian tengah mengarah ke Utara di wilayah Kalimantan Tengah. Meskipun demikian terdapat beberapa kendala yang masih perlu untuk dipertimbangkan antara lain sarana dan prasarana serta infrastruktur penunjang dalam usaha ternak sapi potong. Dengan membandingkan informasi spasial berdasarkan Gambar 2 dan Gambar 4, terdapat beberapa wilayah administrasi yang dapat diprioritaskan untuk pengembangan usaha ternak sapi potong antara lain adalah Kabupaten Kotawaringin Barat, Seruyan, Kotawaringin Timur, Katingan dan Pulang Pisau. Kawasan ini merupakan kesatuan hamparan sehingga sedikit banyak memudahkan dalam penyusunan konsep pembangunan peternakan. Selain itu, dengan makin berkembangnya pembangunan di sektor perkebunan melalui ekspansi areal perkebunan sawit yang mengarah pada tipologi lahan kering, secara langsung akan berdampak pada pertumbuhan sarana dan infrastruktur termasuk ketersediaan sumberdaya manusia baik yang berada di dalam kawasan perkebunan maupun di luar kawasan. Konsep integrasi ternak sapi dalam perkebunan yang disertai teknologi inovasi untuk selanjutnya dapat dijadikan sebagai referensi dalam penyusunan program pembangunan daerah (Diwyanto 1998).

Pengembangan usaha ternak sapi yang sudah eksis pada tipologi lahan basah hingga saat ini masih perlu dipertahankan selain juga tetap dikembangkan. Beberapa faktor pendukung dalam usaha ternak sapi di lahan-lahan basah Kalimantan Tengah adalah ketersediaan sarana dan prasarana termasuk SDM yang cukup memadai mengingat pada tipologi lahan basah sudah terlebih dahulu berjalan program-program pembangunan baik yang berasal dari sektor pertanian, perkebunan maupun sektor peternakan. Dengan mengintroduksikan teknologi inovasi spesifik lokasi yang di dalamnya sudah mencakup teknik pengendalian parasit dan penyakit ternak, maka kawasan tipologi lahan basah masih perlu dikembangkan dan dapat dijadikan sebagai program pengembangan awal sebelum mengarah pada kawasan tipologi lahan kering yang lebih menjanjikan untuk usaha ternak sapi potong di Kalimantan Tengah.

\section{KESIMPULAN}

Jenis parasit yang umum menyerang sapi potong adalah Fasciola sp., Cooperia sp., Paramphistomum sp., dan Trichostrongylus sp., dan serangan parasit cacing Fasciola sp. merupakan jenis yang paling banyak dijumpai pada usaha ternak sapi di Kalimantan Tengah. Sebaran geografis kejadian atau keberadaan serangan parasit cacing pada usaha ternak sapi potong lebih banyak dijumpai pada tipologi lahan basah yang terdapat dibagian sebelah selatan wilayah Kalimantan Tengah. Rekomendasi perencanaan pengembangan ternak sapi di Kalimantan Tengah dapat diarahkan pada tipologi lahan kering yang diprioritaskan pada beberapa wilayah administrasi yaitu Kabupaten Kotawaringin Barat, Seruyan, Kotawaringin Timur, Katingan dan Pulang Pisau.

\section{DAFTAR PUSTAKA}

Adrial, Haryanto B, Irwandi I, Siahaan M, Bhermana A, Widayati N, Muhaimin, Yasir M. 2016. Pengkajian faktor-faktor penghambat peningkatan produktivitas dan penerapan inovasi teknologi pemeliharaan untuk mengoptimalkan produktivitas ternak sapi di Kalimantan Tengah. Laporan Akhir. Palangka Raya (Indonesia): BPTP Balitbangtan Kalimantan Tengah. 
Anggriana A. 2014. Prevalensi infeksi cacing hati (Fasciola sp.) pada sapi Bali di Kecamatan Libureng Kabupaten Bone [Skripsi]. Makassar (Indonesia): Fakultas Kedokteran Universitas Hasanuddin.

Altiery MA. 1987. Agroecology, the scientific basis of alternative agriculture. London (UK): Westview Press.

Ambarisa I, Marsaulina I, Hasan W. 2013. Analisis cacing hati (Fasciola hepatica) pada hati dan feses sapi yang diambil dari rumah potong hewan di Mabar Medan [Internet]. [disitasi 12 Februari 2017]. Tersedia dari: http://download.portalgaruda.org

BMKG. 2012. Analisis dan prakiraan curah hujan se-Kalimantan Tengah. Laporan Meteorologi dan Geofisika. No. 15.

BMKG. 2017. Analisis curah hujan dan sifat hujan bulan Januari 2017 [Internet]. [disitasi 12 Februari 2017]. Tersedia dari: http://www.bmkg.go.id/berita/?p=analisis-curah-hujan-dansifat-hujan-bulan-januari-2017\&lang=ID\&s=detil

BPS Kalimantan Tengah. 2016. Provinsi Kalimantan Tengah dalam angka. Palangka Raya (Indonesia): Badan Pusat Statistik.

Beriajaya, Stevenson P. 1986. Reduced productivity in small ruminant in indonesia as a results of gastrointestinal nematode infections. In: Jainudeen MR, Mahyudin M, Huhn JE, editors. Livestock Production and Disseases in the Tropics. Proceedings of the $5^{\text {th }}$ Conference of Institute of Tropical Veterinary Medicine. Kuala Lumpur, 18-22 August 1986. Selangor (Malaysia): Faculty of Veterinary Medicine and Animals Science, Universiti Pertanian Malaysia. p. I:43-44.

Bhermana A, Hamdan J, Anyar AR, Peli M. 2002. Determination of agricultural land regions using agroecological zone (AEZ) approach and geographic information system. A case study of Kotawaringin Barat Regency, Kalimantan, Indonesia. Proceeding of The Malaysian Society of Soil Science Conference 2002. Application of Modern Tools in Agriculture. p. 36-39.

Coleman A. L and Galbraith, J. M. 2000. Using GIS as an agricultural land-use planning tool. Virginia Agricultural Experiment Station. Bulletin 00-2. Department of Crop and Soil Environmental Science College of Agriculture and Life Sciences Virginia Tech.

Dewi HUN, Soelistijadi R, Sunardi. 2005. Pemanfaatan analisis spasial untuk pengolahan data spasial sistem informasi geografi. J Teknologi Info Dinamik. X:108-116.

Diwyanto K. 1998. Kebijaksanaan dan strategi peneltian dan penembangan peternakan menyongsong abad XXI. Dalam: Haryanto B, Nurhayati DP, Darminto, Supar, Martindah E, penyunting. Prosiding Seminar Nasional Peternakan dan Veteriner. Bogor, 1-2 Desember 1998. Bogor (Indonesia): Puslitbangnak. hlm. 1-12.

Djaenudin D, Sulaeman Y, Abdurachman A. 2002. Pendekatan pewilayahan komoditas pertanian menurut pedo-agroklimat di kawasan Timur Indonesia. J Litbang Pertanian. 21:1-10.

Laurini R, Thompson D. (1992) Fundamentals of spatial information systems. The APIC series No. 37. London (UK): Academic Press.

Martindah E, Widjayanti S, Estuningsih SE, Suhardono. 2005. Meningkatkan kesadaran dan kepedulian masyarakat terhadap fasciolosis sebagai penyakit zoonosis. Wartazoa. 15:143-154.

Oldeman LR, Irsal L, Muladi. 1980. Agro-climatic map of Kalimantan. Bogor (Indonesia): Central Research Institute for Agriculture.

Prahasta E. 2001. Konsep-konsep dasar sistem informasi geografis. Bandung (Indonesia): CV Informatika.

Prasetyo A, Basuki S. 2010. Analisis masalah dan potensi untuk pendekatan teknologi pada sistem usaha tani terpadu tanaman sayuran dan ternak sapi (Studi kasus di Desa Ngablak, Kabupaten Magelang, Jawa Tengah. AGRIPLUS. 20:18-28. 
Pusat Penelitian Tanah dan Agroklimat. 2000. Atlas sumberdaya tanah tingkat eksplorasi skala 1:1.000.000.

Pusat Penelitian Tanah dan Agroklimat. 1995. Peta potensi pengembangan pertanian provinsi Kalimantan Tengah Skala 1:500.000.

Raju, P. L. N. 2004. Fundamentals of geographical information system. In: Sivakumar MVK, Roy PS, Harmsen K, Saha SK. Satellite remote sensing and gis applications in agricultural meteorology. Proceedings of the Training Workshop. Dehra Dun, 7-11 July 2003. Dehra Dun (India). 103-120.

Riady M. 2005. Upaya pengembangan industri peternakan nasional bebas dari penyakit-penyakit strategis [Internet]. [disitasi 12 Februari 2017]. Tersedia dari: http://peternakan.litbang.pertanian.go.id/fullteks/semnas/pro05-1.pdf?secure=1

Richard T, Martin W, McWilliam N, Zukowskyj P. 2005. Field guidelines: GIS, GPS and remote sensing. The expedition advisory centre royal geographical society (with IBG) 1 Kensington Gore London SW7 2AR.

Sadarman, Handoko J, Febrina D. 2007. Infestasi Fasciola sp pada sapi Bali dengan sistem pemeliharaan yang berbeda di Desa Tanjung Rambutan Kecamatan Kampar. J Peternakan. $4: 37-45$.

Santoso U. 2006. Manajemen usaha ternak potong. Jakarta (Indonesia): Penebar Swadaya.

Shereen A, ElDeeb HE, Atiya DM. 2011. A new model for automatic raster-to-vector conversion. Int J Eng Technol. 3:182-190.

Subronto, Tjahayati I. 2004. Ilmu penyakit ternak II. Yogyakarta (Indoensia): Gadjah Mada University Press.

Suhardono, Estuningsih SE, Widjajanti S, Natalia L, Kalianda JS. 1999. Fasciolosis pada kerbau yang dipelihara pada lahan rawa di Provinsi Kalimantan Selatan. Dalam: Haryanto B, Murdiati TB, Djajanegara A, Supar, Sutama IK, Setiadi B, Darminto, Beriajaya, Abubakar, penyunting. Prosiding Seminar Nasional Peternakan dan Veteriner. Bogor, 18-19 Oktober 1999. Bogor (Indonesia): Puslitbangnak. hlm. 571-578.

Tomlinson RF. 1968. A geographical information system for regional planning. Papers of a CSIRO Symposium Organized in Cooperation with UNESCO. Macmillan, 26-31 August 1968. Macmillan (Australia): UNESCO. p. 200-210.

USAID. 2002. Manual for Using ArcView GIS 3.2 and the GIS of G-CAP [Internet]. [cited 12 February 2017]. Available from: http://pdf.usaid.gov/pdf_docs/Pnad1237.pdf

Wirosoedarmo R, Rahadi B, Sasmito DA. 2007. Penggunaan sistem informasi geografi (SIG) pada penentuan lahan kritis di wilayah sub-DAS Lesti Kabupaten Malang. J Ilmu-Ilmu Pertanian Indonesia. Edisi Khusus:452-456.

Yani A, Purwanto BP. 2006. Pengaruh iklim mikro terhadap respons fisiologis sapi Peranakan Fries Holland dan modifikasi lingkungan untuk meningkatkan produktivitasnya. Media Peternakan. 29:35-46.

\section{DISKUSI}

\section{Pertanyaan}

Bagaimana teknologi spesifik lokasi untuk pencegahan penyakit cacingan?

\section{Jawaban}

Sistem penggembalaan ternak jangan terlalu pagi, pemeliharaan intensif dengan pemanfaatan pakan berbasis limbah sawit, program pemberian obat cacing. 